'Gaziosmanpasa University

Medical Faculty, Department of

Emergency, Tokat, Turkey.

${ }^{2}$ Sivas Numune Hospital,

Department of Emergency, Sivas, Turkey. ${ }^{a}$ Assoc. Professor. ${ }^{\mathrm{b}} \mathrm{MD}$.

- Acknowledgements: None declared

Authorship: The conception and design of the work; the

acquisition, analysis, and interpretation of data for the work; drafting the work and revising it critically for important

intellectual content; and final approval of the manuscript was conducted

by Serhat Karaman, Assoc. Prof.

- Funding: None declared.

- Availability of data and

materials: All data is available on

request without restriction.

Conflict of interest: None

declared.

- Informed consent: Written

informed consent was not

necessary because the study

was performed retrospectively

performed by screening patient

files.

Ethical approval: The study was approved by the institutional review board.

- Human rights: The study

was made in following the Declaration of Helsinki for Human Research.

Recibido el 7 de diciembre de 2018, aceptado el 3 de octubre de 2019.

Corresponding Author: Serhat Karaman, Assoc Prof.

Gaziosmanpaşa University

Medical Faculty, Department of Emergency Tasliçiftlik Street, Tokat, Turkey

Telephone: + 90 (356) 25216 16 Fax: + 90 (356) 2521625

Mobile: +905054001506 drserhatkaraman4@hotmail.com

\section{Risk of late appearance of acute myocardial infartion after carbon monoxide $(\mathrm{CO})$ intoxication}

\author{
SERHAT KARAMAN ${ }^{1, a}$, ABUZER COŞKUN ${ }^{2 b}$
}

\begin{abstract}
Background: After acute carbon monoxide intoxication, there may be a higher risk for late adverse cardiac events. However, these patients are usually not followed to monitor the appearance of these effects. Aim: To follow patients seen at an emergency department for carbon monoxide intoxication, monitoring the appearance of myocardial infarction. To assess the predictive value for such complication of serum troponin, carboxyhemoglobin, and procalcitonin levels at the moment of intoxication. Material and Methods: We followed 237 patients receiving emergency care for carbon monoxide intoxication, with a serum carboxyhemoglobin of 5\% or more, between 2010 and 2012. Levels of procalcitonin and troponin I were measured. Patients were followed for five years after the intoxication. Results: During the follow up period, 35 patients had a myocardial infarction. These patients had significantly higher carboxyhemoglobin, procalcitonin and troponin I levels at the moment of the intoxication than their counterparts who did not had a myocardial infarction in the follow up. A logistic regression analysis showed that age, carboxyhemoglobin levels, procalcitonin, troponin 1 and length of CO exposure were associated with a higher risk of myocardial infarction. Procalcitonin, troponin and carboxyhemoglobin levels had a high sensitivity and specificity to predict the appearance of myocardial infarction, with high areas under the receiver operating characteristic (ROC) curves. Conclusions: In patients with CO intoxication, carboxyhemoglobin, troponin and procalcitonin levels at the moment of the intoxication are significant predictors of the late appearance of myocardial infarction.
\end{abstract}

(Rev Med Chile 2019; 147: 1128-1135)

Key words: Carbon Monoxide; Emergency Service, Hospital; Myocardial Infarction; Poisoning; Procalcitonin.

\section{Riesgo de aparición de infarto agudo de miocardio en el largo plazo después de una intoxicación por monóxido de carbono (CO)}

Antecedentes: Después de una intoxicación con monóxido de carbono, hay un mayor riesgo de desarrollar problemas cardiovasculares a largo plazo. Sin embargo, estos pacientes no son seguidos habitualmente para evaluar la aparición de estos eventos. Objetivo: Efectuar un seguimiento de pacientes que han sufrido una intoxicación con CO, evaluando la aparición de infarto del miocardio. Evaluar el valor de los niveles de troponina, carboxihemoglobina y procalcitonina para predecir la aparición de estos eventos. Material y Métodos: Seguimos 237 pacientes que fueron atendidos de urgencia por una intoxicación con CO, con 
niveles de carboxihemoglobina de 5\% o más, entre 2010 y 2012. Se midieron los niveles de procalcitonina, troponina 1 y carboxihemoglobina y los pacientes fueron seguidos por cinco años después de la intoxicación. Resultados: Durante el seguimiento, 35 pacientes tuvieron un infarto al miocardio. Estos pacientes tenían niveles significativamente más altos de procalcitonina, troponina 1 y carboxihemoglobina al momento de la intoxicación, que los pacientes que no tuvieron un infarto durante el seguimiento. Una regresión logística mostró que la edad, carboxihemoglobina, procalcitonina, troponina y la duración de exposición a CO se asociaron a un mayor riesgo de infarto. Procalcitonina, troponina 1 y carboxihemoglobina tuvieron una alta sensibilidad y especificidad para predecir la aparición de infarto, con áreas bajo la curva ROC (receiver operating characteristic) elevadas. Conclusiones: En pacientes con intoxicación por CO, la carboxihemoglobina, procalcitonina y troponina son predictores significativos de la aparición de infarto agudo de miocardio en el largo plazo.

Palabras clave: Atención Ambulatoria; Infarto del Miocardio; Intoxicación por Monóxido de Carbono; Monóxido de Carbono.

arbon monoxide (CO) poisoning, which is the leading cause of toxic deaths, also constitutes an important part of emergency room (ED) applications ${ }^{1,2}$. CO is a colorless, odorless, tasteless and non-irritant gas resulting from poor combustion of carbon-containing fuels. $\mathrm{CO}$ is a heavier gas than air and can accumulate quickly in poorly ventilated indoor environments. $\mathrm{CO}$ is bound to hemoglobin with an affinity 240 times higher than oxygen and disrupts the release and transport of oxygen to tissues by forming carboxyhemoglobin $(\mathrm{COHb})^{3,4}$.

$\mathrm{CO}$, which can cause myocardial depression and hypotension, has a greater affinity to cardiac myoglobin than hemoglobin. CO, combined with myoglobin, leads to a decrease in partial oxygen in muscle tissue and causes rhabdomyolysis. Myocardial infarction (MI) is often associated with CO exposure. Even 5-10\% increases in $\mathrm{COHb}$ levels in people with previous coronary artery disease (CAD) may trigger exercise angina. High levels of $\mathrm{COHb}$ may affect the myocardium even in young and healthy individuals $s^{5,6}$.

Cardiac troponins (cTn) are structural proteins involved in the regulation of skeletal and cardiac muscle contraction with tropomyosin. The complex of troponins $\mathrm{T}$, I and $\mathrm{C}$ enables the interaction of actin and myosin with calcium mediated and fine filaments. Troponins are sensitive and specific markers of heart muscle damage ${ }^{7,8}$.

Procalcitonin (PCT) has been introduced as a new marker of inflammation. The original product of the Calc-1 gene is the 141-amino acid chain of pro-thermicutonin, the C-cells of the thyroid gland are bound by the N-terminus of the endoplasmic reticulum, where it is cleaved by an endopeptidase and ascends to PCT ${ }^{9}$. PCT concentration is undetectable or low in healthy subjects ${ }^{10}$. Recent studies have found that PCT levels correlate with the degree of atherosclerosis in coronary artery disease patients and are even associated with a negative outcome ${ }^{11}$.

The aim of this study was to evaluate the cTn, PCT and COHb levels of patients presenting with ED due to CO intoxication, and the risk of MI that may develop late after treatment and discharge. Determining the parameters predicting the risk of MI that may develop in the late stage of CO intoxication could provide close monitoring and early treatment of the patients.

\section{Material and Methods}

\section{Study design and population}

In this cross-sectional cohort study; between January 2005 and December 2012, 1,869 patients older than 18 years of age who presented to ED for $\mathrm{CO}$ poisoning were screened. 237 patients (129 female, 108 male; mean age $55.17 \pm 9.84$ years; range 29 to 98 years, $54.4 \%$ female) with serum PCT were included in the study.

At the time of admission to the ED, known coronary artery disease (CAD) or other known heart disease, such as valvular diseases or rhythm disorders, cerebrovascular disease, congestive 
heart failure, chronic liver disease, dialysis due to chronic renal failure, infectious, inflammatory disease or malignancy, patients with severe anemia or other hematologic diseases and erythrocyte suspension in the last six months, and patients with hemogram and biochemical tests and serum levels of COHb, cTn and PCT were excluded from the study.

A five-year follow-up registry after discharge from $\mathrm{CO}$ poisoning patients through an annual automation system was reviewed. During this period, patients who did not have access were called by telephone and CAD was questioned. Diagnoses, admission dates, contact information and demographic, clinical and laboratory data are included in the registry system of our hospital. Patient information was reached by call and/or hospital records. CO poisoning patients in the late period; CAD was divided into two groups as developing and non-developing.

Procalcitonin; PCT was studied in 20-30 minutes with Mini Vidas device. Results were considered to be higher than the normal range of 0-0.05 ng/ml.

The patients' $\mathrm{COHb}$ levels were obtained from arterial blood gas analyses using the Acobas ${ }^{\circledR}$ b221 Blood Gassystem (Roche, Basel, Switzerland). A diagnosis of $\mathrm{CO}$ poisoning was made according to the medical history and a $\mathrm{COHb}$ level $>5 \%$. CO exposure time was defined as the approximate duration of $\mathrm{CO}$ inhalation.

Troponin I levels, which were evaluated with in fifteen-minutes after patients were admitted to ED, were measured with a one step immunofluorometric assays and wich method using three monoclonal antibodies (AQ90 Flex, Radiometer Medical ApS, Brønshøj, Denmark). The conventional definition of elevated troponin level is when this value exceeds the 99th percentile value of a healthy reference population and elevated test level, which is $>0.05 \mathrm{ng} / \mathrm{ml}$, for our laboratory, was accepted aspositive. Additionally, nonelevated test level, which is $\leq 0.05 \mathrm{ng} / \mathrm{ml}$, was accepted as negative.

Recurrent electrocardiography (ECG) of the patients with high cTn I levels at the time of admission to the emergency department was performed and troponin follow-up was performed. Patients diagnosed with acute $\mathrm{MI}$ in the late post-discharge period were examined for $\mathrm{cTn} I$ at 0,6 and 12 consecutive hours in ED. Patients with ST elevation in the ECG were taken to the coronary angiography laboratory. AMI diagnoses were determined by cardiologists and emergency medicine specialists in our hospital based on AHA diagnostic criteria. ECGs of the patients; Twelve leads were taken with Cardiofax ECG-9132K (NihonKohden, Tokyo, Japan) at the bedside for ED admission.

The study was made in following the Declaration of Helsinki for Human Researchand was approved by the institutional review board. All patients were given written informed consent and the study was approved by Cumhuriyet University Medical School Ethical Committee.

\section{Statistical Analysis}

The data obtained from this study was analyzed by SPSS 15.0 (SPSS Inc., Chicago, IL, USA) software package. Shapiro Wilk's was used because of the number of units. Mann-Whitney $U$ test was used to examine the differences between the groups because the variables did not come from the normal distribution. Chi-square analysis was used to examine the relationships between groups of nominal variables. Fisher's exact test was used wjen appropriate and Spearman correlation analysis was performed in Monte Carlo Simulation with $\mathrm{RxC}$ tables. In addition, logistic regression was used for univariate and multivariate analyzes of variables. Univariate analysis was used to measure the relationship of variables with CAD development. Variables that were statistically significant in univariate analysis were used in multivariate logistic regression risk model by advanced step method to determine independent prognostic factor for CAD development. 0.05 was used as the level of significance when interpreting the results, and $\mathrm{P}$ values less than 0.05 were considered as significant.

\section{Results}

Main patients' characteristics are shown in Table 1. Baseline characteristics, age, CO exposure time, red cell distribution width (RDW), mean platelate volum (MPV), PCT, COHb and cTn were statistically significant (Table 1 ).

The gender of the patients with late CAD after $\mathrm{CO}$ intoxication was not statistically significant with chi-square test, but diabetes mellitus, hypertension, tobacco use and mortality and MI development were statistically significant (Table 2). 
Table 1. Baseline characteristics of study patients

\begin{tabular}{|c|c|c|c|c|c|}
\hline & $\begin{array}{c}\text { All patients } \\
\text { n: } \mathbf{2 3 7}\end{array}$ & $\begin{array}{c}\text { Patients with } \\
\text { (-) CAD } \\
\text { n: } 202\end{array}$ & $\begin{array}{c}\text { Patients with } \\
\begin{array}{c}\text { (+) CAD } \\
\text { n: } 35\end{array}\end{array}$ & $\mathbf{z}$ & p-value \\
\hline Mean age(y) & $55,17 \pm 9,84$ & $54,21 \pm 9,88$ & $60,12 \pm 13,07$ & $-3,737$ & 0,001 \\
\hline $\begin{array}{l}\text { Famale } \\
\text { Male }\end{array}$ & $\begin{array}{l}129(\% 54,4) \\
108(\% 45,6)\end{array}$ & $\begin{array}{c}109(\% 84,5) \\
93(\% 86,1)\end{array}$ & $\begin{array}{l}20(\% 15,5) \\
15(\% 13,9)\end{array}$ & & 0,727 \\
\hline CRP (mg/L) & $4,07 \pm 6,16$ & $3,92 \pm 5,93$ & $4,95 \pm 7,39$ & $-0,214$ & 0,831 \\
\hline CO ET (h) & $2,99 \pm 1,51$ & $2,65 \pm 1,33$ & $4,97 \pm 0,89$ & $-8,112$ & 0,001 \\
\hline $\operatorname{WBC}\left(10^{\wedge} 3 / \mathrm{uL}\right)$ & $10,28 \pm 3,77$ & $10,40 \pm 3,77$ & $9,61 \pm 3,78$ & $-1,014$ & 0,311 \\
\hline RDW (\%) & $15,08 \pm 2,29$ & $14,92 \pm 2,27$ & $16,04 \pm 2,21$ & $-2,654$ & 0,008 \\
\hline MPV (fL) & $7,97 \pm 0,81$ & $7,82 \pm 0,74$ & $8,82 \pm 0,64$ & $-6,598$ & 0,001 \\
\hline $\mathrm{MCHC}(\mathrm{g} / \mathrm{dL})$ & $33,26 \pm 1,19$ & $33,25 \pm 1,19$ & $33,26 \pm 1,19$ & $-0,633$ & 0,526 \\
\hline $\mathrm{MCV}(\mathrm{fL})$ & $87,11 \pm 8,94$ & $87,15 \pm 8,82$ & $86,86 \pm 9,97$ & $-0,041$ & 0,967 \\
\hline $\mathrm{MCH}(\mathrm{pg})$ & $29,57 \pm 2,27$ & $29,52 \pm 2,29$ & $29,86 \pm 2,12$ & $-1,044$ & 0,297 \\
\hline PCT (ng/dL) & $0,31 \pm 0,51$ & $0,12 \pm 0,20$ & $1,42 \pm 0,34$ & $-11,699$ & 0,001 \\
\hline $\mathrm{COHb}(\%)$ & $31,62 \pm 9,83$ & $28,22 \pm 5,14$ & $51,25 \pm 7,03$ & $-9,253$ & 0,001 \\
\hline $\operatorname{Tn}(\mathrm{ng} / \mathrm{dL})$ & $0,55 \pm 1,41$ & $0,04 \pm 0,14$ & $3,53 \pm 1,71$ & $-9,238$ & 0,001 \\
\hline
\end{tabular}

CAD: Coronary Artery Disease, (+):Positive; (-):Negative; CRP: C reactive protein; CO ET: Carbon monoxide exposure time; WBC: White blood cell; RDW: Red cell distrubution width; MPV:Mean Platelate Volume; MCHC:Mean Corpuscular Hemoglobin Concentration; MCV; Mean Corpuscular Volume; MCH: Mean Corpuscular Hemoglobine; COHb: Carboxyhemoglobin; Tn:Troponin, PCT: Procalcitonin.

MI developed in $35(14.7 \%)$ of 237 patients after 60 months follow-up of patients discharged after $\mathrm{CO}$ poisoning. All patients with MI had $\mathrm{cTn}, \mathrm{COHb}, \mathrm{PCT}$, duration of exposure to $\mathrm{CO}$, MPV and RDW elevation. In terms of MI, age, duration of $\mathrm{CO}$ exposure, cTn, PCT, $\mathrm{COHb}$, MPV and RDW values were significant for univariete analysis. Corrected multivariete binary logistic recession analysis was performed for this purpose. There was a strong positive correlation between these values and MI. MI was also found to be high in diabetes, hypertension and tobacco users.

In univariate analysis, age, exposure to $\mathrm{CO}$, mortality, COHb, PCT, cTn, MPV and RDW levels were found to have a prognostic value. White blood cell (WBC), mean corpuscular volume (MCV), mean corpuscular hemoglobin $(\mathrm{MCH})$, mean corpuscular hemoglobin concentration (MCHC), C-reactive protein (CRP) MI were statistically insignificant. In addition, in multivariate Binary Logistic regression analysis, age, $\mathrm{CO}$ exposure time, mortality, $\mathrm{COHb}, \mathrm{PCT}, \mathrm{cTn}$,
MPV and RDW were associated with increased CAD risk (Table 3 ).

Patients with high levels of $\mathrm{COHb}, \mathrm{cTn}$ and PCT at the time of admission to ED had a higher mortality in the acute period. In addition, it was determined that COHb level was above $40 \%$ in all patients who developed late mortality during the 60 months follow-up period and the duration of cTn, PCT, CO exposure was high and RDW and MPV were elevated, both in uni and multivariate analyses.

There was no significant correlation between CAD and CRP after CO intoxication. However, statistically strong correlation was found between age, exposure time to $\mathrm{CO}$, mortality, $\mathrm{COHb}, \mathrm{PCT}$, cTn, MPV and RDW (Table 4).

Optimal cut-off values of PCT, cTn and COHb to determine 5-year cardiac follow-up positivity in the ROC curve: PCT: $\mathrm{m}>0.855$; sensitivity 98.7\% and specificity $97.3 \%$; cTn: $>0.980$; sensitivity $97.1 \%$ and specificity $96.6 \%$; $\mathrm{COHb}:>42.00$; sensitivity $97.8 \%$ and specificity $95.3 \%(\mathrm{p}=0.001$, Figure 1). 
Risk of myocardial infarction in the late period in cases with carbon monoxide intoxication - S. Karaman et al

Table 2. Chi-square test of coronary artery disease related to gender, mortality and variable risk factors

\begin{tabular}{|c|c|c|c|c|c|}
\hline & & \multicolumn{2}{|c|}{ Coronary Artery Disease } & \multirow[t]{2}{*}{$x^{2}$} & \multirow[t]{2}{*}{ p-value } \\
\hline & & $\begin{array}{c}\text { Negative } \\
\text { n (\%) }\end{array}$ & $\begin{array}{c}\text { Positive } \\
\text { n (\%) }\end{array}$ & & \\
\hline \multirow[t]{2}{*}{ Gender } & \multirow{2}{*}{$\begin{array}{l}\text { Female } \\
\text { Male }\end{array}$} & $109(46)$ & $20(8,4)$ & \multirow{2}{*}{0,122} & \multirow{2}{*}{0,727} \\
\hline & & $93(39,2)$ & $15(6,3)$ & & \\
\hline \multirow[t]{2}{*}{ Mortality } & \multirow{2}{*}{$\begin{array}{l}\text { No } \\
\text { Yes }\end{array}$} & $202(85,2)$ & $0(0)$ & \multirow[b]{2}{*}{47,784} & \multirow[b]{2}{*}{$<0,001$} \\
\hline & & $27(11,4)$ & $8(3,4)$ & & \\
\hline \multirow[t]{2}{*}{ HT } & \multirow{2}{*}{$\begin{array}{l}\text { No } \\
\text { Yes }\end{array}$} & $155(65,7)$ & $18(7,6)$ & \multirow[b]{2}{*}{8,418} & \multirow[b]{2}{*}{$<0,004$} \\
\hline & & $47(19,9)$ & $16(6,8)$ & & \\
\hline \multirow[t]{2}{*}{ DM } & \multirow{2}{*}{$\begin{array}{l}\text { No } \\
\text { Yes }\end{array}$} & $154(65)$ & $13(5,5)$ & \multirow{2}{*}{21,907} & \multirow{2}{*}{$<0,001$} \\
\hline & & $48(20,3)$ & $22(9,3)$ & & \\
\hline \multirow[t]{2}{*}{ Tobacco } & No & $141(59,5)$ & $12(5,1)$ & \multirow[b]{2}{*}{16,446} & \multirow[b]{2}{*}{$<0,001$} \\
\hline & Yes & $61(25,7)$ & $23(9,7)$ & & \\
\hline
\end{tabular}

HT: Hypertension, DM: Diabetes Mellitus.

Table 3. Univariate and Multivariate Analysis of Variables with Myocardial Infarction

\begin{tabular}{|c|c|c|c|c|c|c|c|c|}
\hline & \multicolumn{8}{|c|}{ Coronary Artery Disease } \\
\hline & \multicolumn{4}{|c|}{ Univariate } & \multicolumn{4}{|c|}{ Multivariate } \\
\hline & $\begin{array}{c}\text { Cox } R \\
\text { sqaure }\end{array}$ & HR & $95 \% \mathrm{Cl}$ & p-value & $\begin{array}{c}\text { Cox } R \\
\text { square }\end{array}$ & HR & $95 \% \mathrm{Cl}$ & p-value \\
\hline Age & 0,056 & 1,077 & $1,033-1,122$ & $<0,001$ & & 1,492 & $1,718-1,870$ & $<0,001$ \\
\hline CO ET & 0,271 & 3,952 & $2,545-6,136$ & $<0,001$ & & 4,266 & $4,592-8,632$ & $<0,001$ \\
\hline PCT & 0,530 & 40,003 & $20,287-90,013$ & $<0,018$ & & 42,017 & $22,872-94,004$ & $<0,001$ \\
\hline $\mathrm{COHb}$ & 0,511 & 1,651 & $1,342-2,031$ & $<0,001$ & 0,567 & 1,919 & $1,843-2,487$ & $<0,001$ \\
\hline Tn & 0,538 & 86,814 & $9,633-782,409$ & $<0,001$ & & 40,035 & $1,576-1016,755$ & $<0,004$ \\
\hline Mortality & 0,029 & 5,610 & $3,501-8,989$ & $<0,001$ & & 0,114 & $0,039-0,331$ & $<0,001$ \\
\hline MPV & 0,204 & 8,923 & $4,194-18,984$ & $<0,001$ & & 9,230 & $6,941-21,849$ & $<0,027$ \\
\hline RDW & 0,025 & 1,192 & $1,030-1,379$ & $<0,019$ & & 1,236 & $1,045-1,461$ & $<0,001$ \\
\hline WBC & 0,006 & 0,941 & $0,848-1,044$ & $>0,252$ & & & & \\
\hline MCV & 0,000 & 0,996 & $0,959-1,036$ & $>0,857$ & & & & \\
\hline $\mathrm{MCH}$ & 0,003 & 1,065 & $0,918-1,236$ & $>0,407$ & & & & \\
\hline $\mathrm{MCHC}$ & 0,001 & 1,068 & $0,793-1,440$ & $>0,663$ & & & & \\
\hline CRP & 0,003 & 1,024 & $0,974-1,076$ & $>0,361$ & & & & \\
\hline
\end{tabular}

Cl: Confidence Interval, HR: Hazard Ratio. 
Table 4. Spearman correlation coefficients for late-period coronary artery disease

\begin{tabular}{|lcr|}
\hline & \multicolumn{2}{c}{ Myocardial Infarction } \\
& $\mathbf{r}$ & p-value \\
\hline PCT & 0,762 & $<0,001$ \\
COHb & 0,602 & $<0,001$ \\
\hline Tn & 0,601 & $<0,001$ \\
CO ET & 0,528 & $<0,001$ \\
Mortality & 0,449 & $<0,001$ \\
RDW & 0,173 & $<0,008$ \\
MPV & 0,430 & $<0,001$ \\
Age & 0,243 & $<0,001$ \\
CRP & 0,014 & $>0,831$ \\
\hline
\end{tabular}

\section{Discussion}

There are few studies on the late effects of $\mathrm{CO}$ intoxication. As far as we can search in the literature, we have not been able to detect a study to determine the risk of late development of $\mathrm{COHb}$, cTn and PCT levels in ED applications of patients diagnosed with $\mathrm{CO}$ intoxication.

Since CO poisoning can be acute or chronic, cardiac damage is based on 2 mechanisms: the first is ischemic damage and $\mathrm{COHb}$ binds to both proteins instead of oxygen; the second is toxic damage directly caused by $\mathrm{CO}^{13-18}$. As a result, endothelial damage occurs due to enzymes induced during apoptotic process and free radical formation ${ }^{19}$. CO has shown to trigger venous, arterial and even stent thrombosis and has a prothrombotic effect $^{20-23}$. Myocardial damage includes areas of focal necrosis, more prominent in the subendocardium. Focal perivascular infiltrations and punctate hemorrhages may also be observed. Cardiac biomarkers such as brain natriuretic peptide, troponin, creatinkinase and creatinkinase-MB and $\mathrm{CO}$ elevation, $\mathrm{T}$ wave changes, premature atrial beat and sinus tachycardia have been shown to be associated with CO intoxication ${ }^{24,25}$.

Gender and age differ in many studies in the literature. In our study, most patients were women and the mean age was 55 years. Kaya et al. ${ }^{26}$, reported an incidence of $60 \%$ of women and age mean was 36.36 years while in Durak study ${ }^{27} 72 \%$ were male with an age mean of 33 years. Coşkun et al. ${ }^{28}$

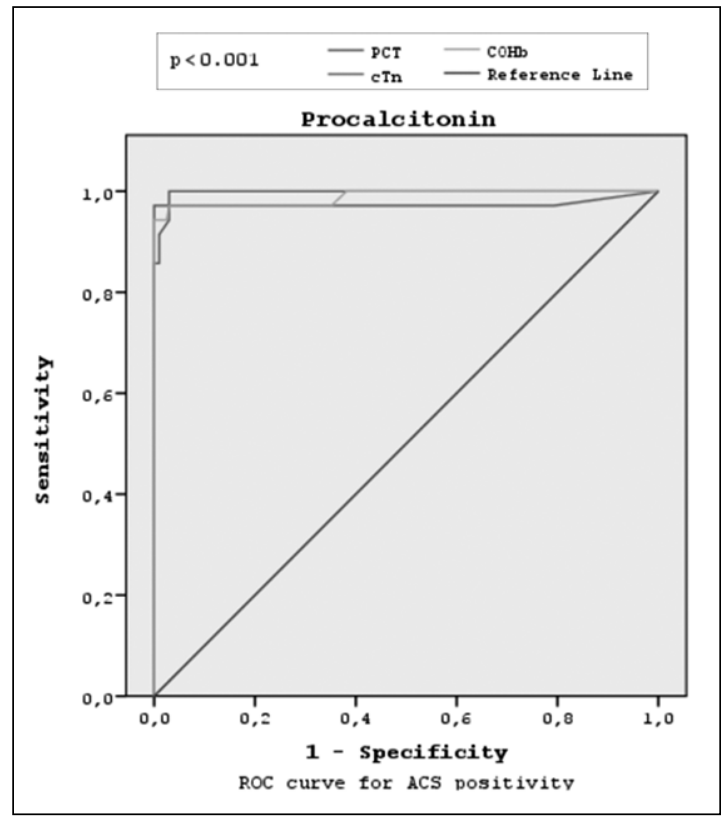

Figure 1. ROC curve analysis according to procalcitonin coronary artery disease positivity.

study showed a $60 \%$ of women with an age mean of 53 years. Age differences among series may be due to particular demographic characteristics.

While there are many studies on acute effects of $\mathrm{CO}$ intoxication, late effects are very few or case-level studies. Henry et al. ${ }^{29}$ found that death due to acute myocardial injury in patients with CO intoxication occurred after 7.6 years. In a study with a mean follow-up of 10.6 years after $\mathrm{CO}$ intoxication, this condition was reported as an independent predictor of all mortality events in the long term ${ }^{30}$.

Cardiac damage may occur in the acute phase of CO intoxication but may also occur in the late period. Arrhythmias such as palpitations, sinus tachycardia, atrial fibrillation, ventricular extrasystole may be observed. In severe cases, bradycardia and atrioventricular complete block may be seen ${ }^{31}$. It may trigger angina pectoris and $\mathrm{MI}$ in patients with ischemic heart disease. ST segment and T wave changes can be seen in ECG. There may be transient right and/or left ventricular wall movement disorders ${ }^{32}$.

The underlying cause of coronary artery disease is atherosclerosis, an inflammatory disease. Kafkas et al. ${ }^{33}$ measured PCT, IL-6, CKMB, tro- 
ponin I and C-reactive protein levels in AMI at admission and at certain hours and found PCT levels to be elevated in patients with AMI. Eren et al. $^{34}$ have shown that increased PCT levels are associated with the degree of atherosclerosis in patients with CAD and peripheral arterial disease.

In our study, PCT was found to be high due to inflammation, which is the basis of CAD and also triggered by $\mathrm{CO}$ poisoning. It was observed that PCT was noticeably low in patients without $\mathrm{MI}$ and with low $\mathrm{COHb}$ and cTn. These findings support the reports indicating that PCT may be elevated in silent, secondary or MI cases due to inflammatory events following CO intoxication.

Sinning et al. ${ }^{35}$ reported that increased PCT levels at baseline were associated with increased cardiovascular event rate and higher mortality at follow-up. Ataoğlu et al. ${ }^{9}$ measured PCT levels at the time of admission and after 48 hours in patients with ACS and reported that high PCT concentrations showed increased 6-month mortality in patients with severe myocardial injury after infarction at 48 hours after admission. We found a significant relationship between mortality and PCT levels from blood samples taken at the time of admission to the emergency department for $\mathrm{CO}$ poisoning. At the same time, this relationship was found to be present with $\mathrm{COHb}, \mathrm{cTnI}, \mathrm{RDW}$ and MPV levels. COHb, PCT and cTnI elevations were found to be associated with increased mortality in $\mathrm{CAD}$, consistent with the literature.

In the study of Kalay et al. ${ }^{36}$ it is the first study to show that high $\mathrm{COHb}$ level is an independent predictor for MI in the long term. Increased Tn due to $\mathrm{CO}$ intoxication and $\mathrm{COHb}$ were associated with blood levels and CO exposure, whereas the present study showed that increased $\mathrm{COHb}$ levels and long-term CO exposure were independent predictors of MI development.

In our study, cTn, PCT and COHb levels increased with increasing $\mathrm{CO}$ exposure time. However, as shown, the rate of cardiac injury and mortality was also increased.

\section{Study limitations}

The biggest limitation of the study was that it was single-centered and retrospective. Therefore, it was difficult to access some data. Some of these were the failure to regain control PCT, cTn, arterial blood gas, $\mathrm{COHb}$ levels after admission to $\mathrm{ED}$, and angiography and echocardiography results were other limitations. There was no history of drug use that could affect CAD prognosis.

\section{Conclusion}

In case of $\mathrm{CO}$ intoxication, patients should be evaluated for immediate effects, even if they are asymptomatic with emergency treatment. Considering the PCT, COHb and cTn levels evaluated in our study, it can be a guide in providing follow-up and early treatment by predicting future cardiac problems. In addition, further studies are needed to show how the immediate treatment of $\mathrm{CO}$ intoxication affects late effects.

\section{References}

1. Ernst A, Zibrak JD. Carbon monoxide poisoning. N Engl J Med 1998; 339: 1603-8.

2. Weaver LK. Carbon monoxide poisoning. N Engl J Med 2009; 360: 1217-25.

3. Committee of the Environmental and Occupational Health Assembly of the American Thoracic Society. State of the Art. Health effects of outdoor air pollution. Am J Respir Crit Care Med 1996; 153: 477-98.

4. Kandis H, Katırcı Y, Çakır Z, Aslan Ş, Uzkeser M, Bilir Ö. Retrospective Analysis of Embolic Carbon Monoxide Intoxication Cases. Academic Emergency Med J 2007; 5: 21-5.

5. Stanley T. Omaye, Metabolic Modulation of Carbon Monoxide Toxicity. Toxicology 2002; 180: 139-50.

6. Katırc1 Y. The frequency and associated factors of neuropsychiatric disorders in patients poisoned with carbon monoxide. Master thesis; Erzurum, Turkey, 2005.

7. Bassand JP, Hamm CW, Ardissino D, Boersma E, Budaj A, Fernández-Aviles F, et al. Guidelines for the diagnosis and treatment of non-ST-segment elevation acute coronary syndromes. Task Force for Diagnosis and Treatment of Non-ST-Segment Elevation Acute Coronary Syndromes of European Society of Cardiology. Eur Heart J 2007; 28: 1598-660.

8. Panteghini M, Pagani, Yeo KT, Apple FS, Christenson $\mathrm{RH}$, Dati F, et al. Evaluation of imprecision for cardiac troponin assays at low-range concentrations. Clin Chem 2004; 50: 327-32.

9. Ataoglu HE, Yilmaz F, Uzunhasan I, Cetin F, Temiz L, Döventas YE, et al. Procalcitonin: A novel cardiac marker with prognostic value in acute coronary syndrome. J Int Med Res 2010; 38: 52-61.

10. Kelly D, Khan SQ, Dhillon O, Quinn P, Struck J, Squi- 
re LB, et al. Procalcitonin as a prognostic marker in patients with acute myocardial myocardial infarction. Biomarkers 2010; 15: 325 -31.

11. Remskar M, Horvat M, Hojker S, Noc M. Procalcitonin in patients with acute myocardial infarction. Wien Klin Wochenschr 2002; 114: 205-10.

12. Senturk T, Cordan J, Baran I, Özdemir B, Güllülü S, Aydınlar A, Güral G. Procalcitonin in patients with acute coronary syndrome: Correlation with high-sensitive C-reactive protein, prognosis and severity of coronary artery disease. Acta Cardiol 2007; 62: 135-41.

13. Horner JM. Anthropogenic emissions of carbonmonoxide. Rev Environ Health 2000; 15 (3): 289-98.

14. Boehning D, Moon C, Sharma S, Hurt KJ, Hester HD, Ronnett GV, et al. Carbon monoxide neurotransmission activated by CK2 phosphorylation of heme oxygenase- 2 . Neuron 2003; 40 (1): 129-37.

15. Weaver LK. Clinical practice. Carbon monoxide poisoning. N Engl J Med 2009; 360 (12): 1217-25.

16. Omaye ST. Metabolic modulation of carbon monoxide toxicity. Toxicology 2002; 180 (2): 139-50.

17. Hampson NB. Emergency department visits for carbon monoxide poisoning in the Pacific Northwest. J Emerg Med 1998; 16 (5): 695-8.

18. Townsend CL, Maynard RL. Effects on health of prolonged exposure to low concentrations of carbon monoxide. Occup Environ Med 2002; 59 (10): 708-11.

19. Thom SR, Fisher D, Xu YA, Notarfrancesco K, Ischiropoulos $\mathrm{H}$. Adaptive responses and apoptosis in endothelial cells exposed to carbon monoxide. Proc Natl Acad Sci USA 2000; 97: 1305-10.

20. FranchiniM, Mannucci PM. Short-term effects of air pollution on cardiovascular diseases: outcomes and mechanisms. J Thromb Haemost 2007; 5: 2169-74.

21. Baccarelli A, Martinelli I, Zanobetti A, Grillo P, Hou LF, Bertazzi PA, et al. Exposure to particulate air pollution and risk of deep vein thrombosis. Arch Intern Med 2008; 168: 920-7.

22. Franchini M, Mannucci PM. Particulate air pollution and cardiovascular risk: shortterm and long-term effects. Semin Thromb Hemost 2009; 35: 665-70.

23. Dileo PA, Tucciarone M, Castro ER, Guerrero M. Late stent thrombosis secondary to carbon monoxide poisoning. Cardiovasc Revasc Med 2011; 12: 56-8.

24. Gandini C, Castoldi AF, Candura SM, Locatelli C, Butera B, Priori S, et al. Carbon monoxide cardiotoxicity.
J Toxicol Clin Toxicol 2001; 39: 35-44.

25. Teksam O, Gumus P, Bayrakci B, Erdogan I, Kale G. Acute cardiac effects of carbon monoxide poisoning in children. Eur J Emerg Med 2010; 17 (4): 192-6.

26. Kaya H, Coşkun A, Beton O, Zorlu A, Kurt R, Yücel H, et al. COHgb levels predict the long-term development of acute myocardial infarction in $\mathrm{CO}$ poisoning. American Journal of Emergency Medicine 2016; 34: 840-4.

27. Durak D. Deaths due to carbon monoxide poisoning. Bursa State Hospital Bulletin 1999; 15 (2): 131-3.

28. Coşkun A, Eren FA, Eren ŞH, Korkmaz İ. Predicting of neuropsychosis in carbon monoxide poisoning according to the plasma troponin, $\mathrm{COHb}$, RDW and MPV levels. American Journal of Emergency Medicine 2019; 37 (7): 1254-59.

29. Henry CR, Satran D, Lindgren B, Adkinson C, Nicholson CI, Henry TD. Myocardial injury and long-term mortality following moderate to severe carbon monoxide poisoning. JAMA 2006; 295 (4): 398-402.

30. Hampson NB, Rudd RA, Hauff NM. Increased long-termmortality among survivors of acute carbon monoxide poisoning. Crit Care Med 2009; 37 (6): 1941-7.

31. Lee D, Hsu TL, Chen CH, Wang SP, Chang MS. Myocardial infarction with normal coronary artery after carbon monoxide exposure: a case report. Zhonghua Yi Xue Za Zhi (Taipei) 1996; 57: 355-9.

32. McMeekin JD, Finegan BA. Reversible myocardial dysfunction following carbon monoxide poisoning. Can J Cardiol 1987; 3: 118.

33. Kafkas N, Venetsanou K, Patsilinakos S, Voudris V, Antonatos D, Kelesidis K, et al. Procalcitonin in acute myocardial infarction. Acute Card Care 2008; 10 (1): 30-6.

34. Erren M, Reinecke H, Junker R, Fobker M, Schulte H, Schurek JO, et al. Systemic inflammatory parameters in patients with atherosclerosis of the coronary and peripheral arteries. Arterioscler Thromb Vasc Biol 1999; 19: 2355-63.

35. Sinning CR, Sinning JM, Schulz A, Schnabel RB, Lubos E, Wild PS, et al. AtheroGene Study Investigators. Association of serum procalcitonin with cardiovascular prognosis in coronary artery disease. Circ J 2011; 75: 1184-91.

36. Kalay N, Ozdogru I, Cetinkaya Y, Eryol NK, Dogan A, Gül I, et al. Cardiovascular effects of carbon monoxide poisoning. Am J Cardiol 2007; 99 (3): 322-4. 